Article

\title{
Käthe Kollwitz: Memorialization as Anti-Militarist Weapon
}

\author{
Ann Murray ${ }^{\mathbb{D}}$ \\ Independent Scholar, T12 VH72 Cork, Ireland; annmrry@gmail.com
}

Received: 13 November 2019; Accepted: 30 January 2020; Published: 10 March 2020

check for updates

\begin{abstract}
This essay explores Käthe Kollwitz's antiwar graphic work in the context of the German, and later, international No More War movement from 1920 to 1925, where it played an important role in antimilitarist campaigns, exhibitions, and publications, both in Germany and internationally. Looking at Kollwitz's production closely, we discover a deeply pragmatic artistic strategy, where the emotionality of Kollwitz's famed prints was the result of tireless technical, formal, and compositional investigation, contrived to maximize emotional impact. By choosing the easily disseminated medium of printmaking as her main vehicle and using a deliberately spare but powerful graphic language in carefully chosen motifs, Kollwitz intended her art to reach as broad an audience as possible in engaging antiwar sentiment. In connection with the leading antiwar voices of the time, including French Nobel Prize-winning writer Romain Rolland and the founder of War Resisters' International, Helene Stöcker, she deployed her work to reach beyond the confines of the art gallery, into internationally distributed posters, periodicals, and books.
\end{abstract}

Keywords: World War I; German art; antiwar; Käthe Kollwitz; Weimar; printmaking; graphic art; antimilitarism; memory; memorialization; No More War movement; modernism

When someone dies because he has been sick—even if he is still young — the event is so utterly beyond one's powers that one must gradually become resigned to it. He is dead because it was not in his nature to live. But it is different in war. There was only one possibility, one point of view from which it could be justified: the free willing of it. And that in turn was possible only because there was the conviction that Germany was in the right and had the duty to defend herself. At the beginning it would have been wholly impossible for me to conceive of letting the boys go as parents must let their boys go now, without inwardly affirming it-letting them go simply to the slaughterhouse. There is what changes everything. The feeling that we were betrayed then, at the beginning. And perhaps Peter would still be living had it not been for this terrible betrayal. Peter and millions, many millions of other boys. All betrayed.

Käthe Kollwitz, 19 March $1918 .^{1}$

1 Kollwitz (1988, p. 87), original German in (Bohnke-Kollwitz 2012, p. 359). In Bohnke-Kollwitz, the text is dated 20 March 1918. Hans Kollwitz's English language edition of his mother's diary and letters, originally published in 1955, includes only a very limited number of diary entries and letters. Hans's much more extensive German compilations include (Kollwitz 1981, 1985). Bohnke-Kollwitz's edition of her grandmother's diaries (Jutta was Hans's daughter) is comprehensive (accompanied by detailed notes), though it is possible that not all entries are included. Where an entry also appears in the English edition of the diaries and letters, the references for both the English and the German edition will be given. In all other German sources, the translations are my own. 
This essay explores the graphic work of Käthe Kollwitz within the context of the German, and later, the international No More War movement, during the years 1920-1925. ${ }^{2}$ Acknowledging Kollwitz's well-documented pacifism in the post-World War I years, it argues that a more nuanced analysis of Kollwitz's work is central to understanding the politics of war memorialization in Germany, specifically her pragmatism in the creative process and in the dissemination of her work, as well as the appreciation of her work by her contemporaries as affective antiwar art. While this essay necessarily excludes detailed discussion of every war-related image by Kollwitz during the period, it provides insights into key actions by her that have been little discussed in the literature, namely the conditions surrounding the development of the drawing and corresponding woodcut Two Dead and the woodcut Memorial Sheet for Karl Liebknecht, the process and dissemination of her cycle of woodcuts War to an international audience by 1925, and the posters The Survivors and No More War, the latter having been created for the Nie wieder Krieg! [No more War!] rally on the Augustusplatz in Leipzig, August 1924. The essay is supported by material from the artist's diaries and letters, some of which remains unavailable to English language readers.

Kollwitz's war art, though studied more than most German examples, has not received the same depth of scholarly investigation as that by artists such as George Grosz, for example. ${ }^{3}$ While some recent German-only publications offer new insights, it is remarkable that Claire Whitner's catalogue, at the time of writing, is the first in English since Elizabeth Prelinger's, when the latter argued that 'it has served the interests of critics to present Kollwitz as a figure of unwavering resolution, progressive in terms of politics and feminism, without heeding her consistently critical and skeptical attitude toward her work and her ambivalent ideological and artistic stances'. Prelinger recalled that because Kollwitz adhered to figuration in the age of abstraction, was a woman in a male-dominated field, and focused on socially-engaged art when it was unfashionable, her remarkable development in terms of form and technique has been largely overlooked. ${ }^{4}$ Additionally, and as first noted by Elizabeth McCausland in 1937, Judith Sharp has voiced criticism of the overemphasis on emotionality, as well as the tendency to overlook Kollwitz's witness to war, which has arguably caused her war imagery to be less rigorously studied. ${ }^{5}$ Most critically, most of her very substantial body of letters and diaries, which are offer unique insights into her artistic practice, remain untranslated.

The artist's extensive diaries and letters convincingly reveal a pragmatic artist working to extract maximum impact. Questions of form and method governed the design of her work, the creation of which was motivated by the sense of betrayal that led to so many deaths. Moreover, while the death of her son Peter (who fell on the battlefield in the earliest weeks of World War I) undoubtedly marked her work and feeds our understanding of it (and it remains a remarkable expression of loss and testament to suffering on the home front), the evidence shows that Kollwitz's commitment to the No More War movement was pursued energetically and objectively. Indeed, her diaries tell us that she could only make art when she could distance herself from her personal experience, that is, separate the artist from the mother. On 22 August 1916, she wrote in her diary that 'for work, one must be hard and thrust outside oneself what one has lived through. As soon as I begin to do that, I again feel myself a

2 The German Nie wieder Krieg [No More War] movement (not to be confused with the British No More War Movement (NMWM), founded 1921) existed from the beginning of World War I, growing to much greater numbers by 1920, the first year that the major annual demonstrations were held in various German cities on the anniversary of the outbreak of World War I (1 August 1914), and which would continue in force until 1925, when numbers had already begun to wane. By 1921, more than twenty antiwar organisations had been formed in Germany as part of the Nie wieder Krieg movement. See for example (Bader 1979). For insight into postwar German politics and society in relation to war commemoration, see for example (Ziemann 2013).

3 A rich body of antiwar art was produced in Germany between 1914 and 1945, and many of the artists remain little studied. See (Heckmann and Ottomeyer 2009).

4 (Whitner 2016; Prelinger 1992, pp. 13-14). Kollwitz was included in (Siebrecht 2013). German-only publications include (Hoffmann 2018; Käthe Kollwitz-Museum 2017).

5 (Sharp 2011, p. 87); (McCausland 1937, p. 23). 
mother who will not give up her sorrow' ${ }^{6}$ Like the younger activist artists George Grosz and John Heartfield, she deliberately mobilized her art to reach far beyond gallery walls and into mass-produced publications and posters. As the opening quotation of this essay indicates, Kollwitz believed in the war effort at first - even though war was repulsive to her-because she, like many other Germans, thought Germany was fighting a defensive war. Reflecting on the somber mood that prevailed during the first weeks of war, she felt that 'in such times it seems so stupid that the boys must go to war. The whole thing is so ghastly and insane. Sometimes the foolish thought: how can they possibly take part in such madness and then the cold shower: they must, must' ${ }^{7}$ It was this belief that led her to support her underage son Peter's pleadings to his father (Kollwitz's husband Karl) that he be allowed to enlist. It was, she recalled, 'this sacrifice to which [Peter] tore me and to which we tore Karl' ${ }^{8}$ In 1918 , by which time she had become disgusted by the mass death of young men, she was compelled to respond, by open letter, to poet Richard Dehmel's urging on 22 October 1918 in the newspaper Vorwärts for one last volunteering drive. ${ }^{9}$ Printed in the Social Democrats (SPD)'s newspaper Vorwärts on 28 October, and reprinted in the liberal Vossische Zeitung, Kollwitz forcefully challenged Dehmel's appeal for new volunteers, likely to consist of the last of Germany's youth, whose deaths 'would be worse and more irreplaceable for Germany than the loss of whole provinces'. Cautioning that 'a world war did not drain [Dehmel's] blood when he was twenty', she concluded: 'There has been enough of dying! Let not another man fall! Against Richard Dehmel I ask that the words of an even greater poet be remembered: "Seed for the planting must not be ground". 10

Over the succeeding years, her involvement with the No More War movement grew. Kollwitz and many others were urged towards antiwar activism by the positive image and presence of militarism that persisted in postwar Germany. While organizations such as the Reichsbanner Schwarz-Rot-Gold were set up to defend democracy against extremist militant factions, the taste for militarism, as Kollwitz was aware, remained an enduring element of the national identity. ${ }^{11}$ Kollwitz refused to commit to any political party (which induced guilt in her), despite the alignment of her socially invested art with the concerns of the left (e.g., Communist Party, KPD) and widespread public recognition of that fact. ${ }^{12}$ But while Kollwitz felt that the SPD-led government could not do enough for the poor in the wake of the war, she was repulsed by the Communists' readiness to use violence, even if they were, as she put it in 1918, hungry, disenfranchised people. ${ }^{13}$ Her work pursued only one objective: no more war.

Kollwitz's major work of the period 1919-1925 was the cycle of woodcuts, War, completed in 1923 and published in Dresden in 1924 by the Emil Richter gallery (which would serve as Kollwitz's exclusive publisher until 1930). As her numerous drawings and print trials indicate, she dwelt deeply on the cycle's content as well as the suitability of media. Her letter to her son dated 31 January 1918 reveals that she had begun to develop the prints, for which she had already made numerous studies:

\footnotetext{
Kollwitz (1988, p. 72). Original German (Bohnke-Kollwitz 2012, p. 269).

Kollwitz (1988, p. 65). Original German in (Bohnke-Kollwitz 2012, pp. 165-66).

Diary entry, Monday, 10 August 1914, in (Bohnke-Kollwitz 2012, p. 152).

Dehmel (1918, p. 7). Translated article title: Sole Salvation.

10 Kollwitz (1918, p. 3). Translated article title: To Richard Dehmel! A Response from Käthe Kollwitz. The article is translated into English in Han's Kollwitz's edition. See (Kollwitz 1988, pp. 88-89). The 'greater poet' Kollwitz refers to is Goethe.

11 Popular publications such as those by the Reicharchiv [Reich Archive] fulfilled an important role in publishing the accounts of ordinary soldiers' war experiences, but there was little to debunk what cultural historian George Mosse called the Myth of the War Experience, which glorified military experience as a 'man-making' exercise while playing down the savagery of modern warfare and its physical and psychological impact on soldiers. See (Mosse 1991). Militant organizations such as the Freikorps and the Stahlhelm were formed barely a month after the Armistice and played a cardinal role in converting the myth into a militarized, political mass movement. For a detailed account of postwar Germany and militarism, see, for example, Bessel' (1993) landmark study.

12 'I am ashamed that I still do not take sides and almost suspect that if I declare that I belong to no party, the real reason for this is cowardice. Actually, I am not revolutionary at all, but evolutionary, because I am praised as an artist of the proletariat and the revolution and I am increasingly pushed into the role'. Diary entry, October 1920 (no exact date given). See (Bohnke-Kollwitz 2012, p. 483).

13 Diary entry, 8 December 1918 (ibid., p. 388).
} 
I'm back in the middle of etching ( . . . ). Yes, I jumped with both feet into a work that I suspected was always hovering darkly since 1914 but which I postponed again and again. Now it seemed like a direct call to me and I started it. Plates about the War. Until now only drawings existed. Never shown to anyone. Drawn under tears. ${ }^{14}$

These earliest drawings that predate the first print trials are lost with the exception of Die Witwe [The Widow] (1915). From this time to 1923, she worked intermittently to arrive at a satisfying pictorial conclusion, but abandoned etching in favor of woodcut:

I first began the War series as etchings. Came to nothing. Dropped everything. [ ... ] If woodcutting fails, then I have proof that the fault lies only within myself. Then I am just no longer able to do it. In all the years of torment these small oases of joys and successes! ${ }^{15}$

The cycle would be worked upon intermittently while Kollwitz developed two other pieces, the drawing Two Dead [Zwei Tote] (1920, Figure 1), upon which she based her first ever woodcut, and her first major woodcut-ironically, perhaps-a memorial to the murdered Liebknecht. The little known Two Dead was Kollwitz's first widely disseminated antiwar picture. A rare image of soldiers in Kollwitz's oeuvre, the drawing was created in 1919 as the title-page illustration to the German publication of Romain Rolland's powerful pacifist drama set during the Boer War, Le temps viendra (The Time Will Come, German: Die Zeit wird kommen, 1903), which would be staged by Erwin Piscator in Berlin in 1922. Kollwitz had seemingly found in Rolland's play, where the conscience of the individual is pitted against one's national duty as a soldier of war, the literary equivalent of her developing antiwar art. ${ }^{16}$ As Stefan Zweig described Le temps viendra, it dealt with the only authority that Rolland recognized, i.e., conscience, which was the essence of Kollwitz's protest against Dehmel. ${ }^{17}$ Two Dead centers on an event late in Act Two, involving the twenty-year-old British soldier Alan and an unnamed Italian volunteer, who is a prisoner of war in Alan's regiment. During an escape attempt, the Italian and Alan mortally wound each other. As they lay dying, they comfort each other, trying to understand the forces that brought them to kill each other. Another soldier, Ebenezzer, watching them, says 'these pigs, these pigs of bankers, ministers, generals, thieves who send the poor to death and damnation for their ambition and their money'. Alan tries to reach out to the Italian, who moves, straightens, tilts, and embraces him. They sink into death. A third soldier, Owen, Alan's friend, vows, in the last line of Act II, that he will never kill again.

There is no surviving written record of why Kollwitz chose this scene above others and the artistic challenges she may have encountered in developing the final composition are restricted to her comments on the later woodcut. But the idea that the soldiers had been fooled into fighting and dying, as voiced by Ebenezzer, surely resonated with Kollwitz, as it clearly echoed Kollwitz's feelings as recorded in the diary entry of 19 March 1918 (see opening quote).

14 Kollwitz reveals in this letter that she was also hesitant to make known her experiences and feelings on the war, as well as the discrepancy she felt between the themes of life and death and the 'stuperous nature of studio work'. See (Bohnke-Kollwitz 1992, p. 163).

15 Diary, 25 June 1920. See (Kollwitz 1988; Bohnke-Kollwitz 2012, p. 477). The italics are used only in Bohnke-Kollwitz.

16 Kollwitz's drawing illustrated the title page of the fourth and fifth printings of the German version, (Rolland 1921) and the version of the drawing used for the title page is lost (Nagel 1972, p. 354). Each copy is numbered up to a total of 1000 copies. The play was written in 1903 and explored numerous antiwar themes through an episode in the Boer War (1899-1902). Rolland described Kollwitz in 1927 thus: 'The work of Kaethe Kollwitz, which reflects the ordeal and pain of the humble and simple, is the grandest German poem of this age. This woman of virile heart has looked on them, has taken them into her motherly arms, with a solemn and tender compassion. She is the voice of the silence of the sacrificed'. See for example (Bittner 1959, p. 8).

17 (Zweig 1921, p. 119). 


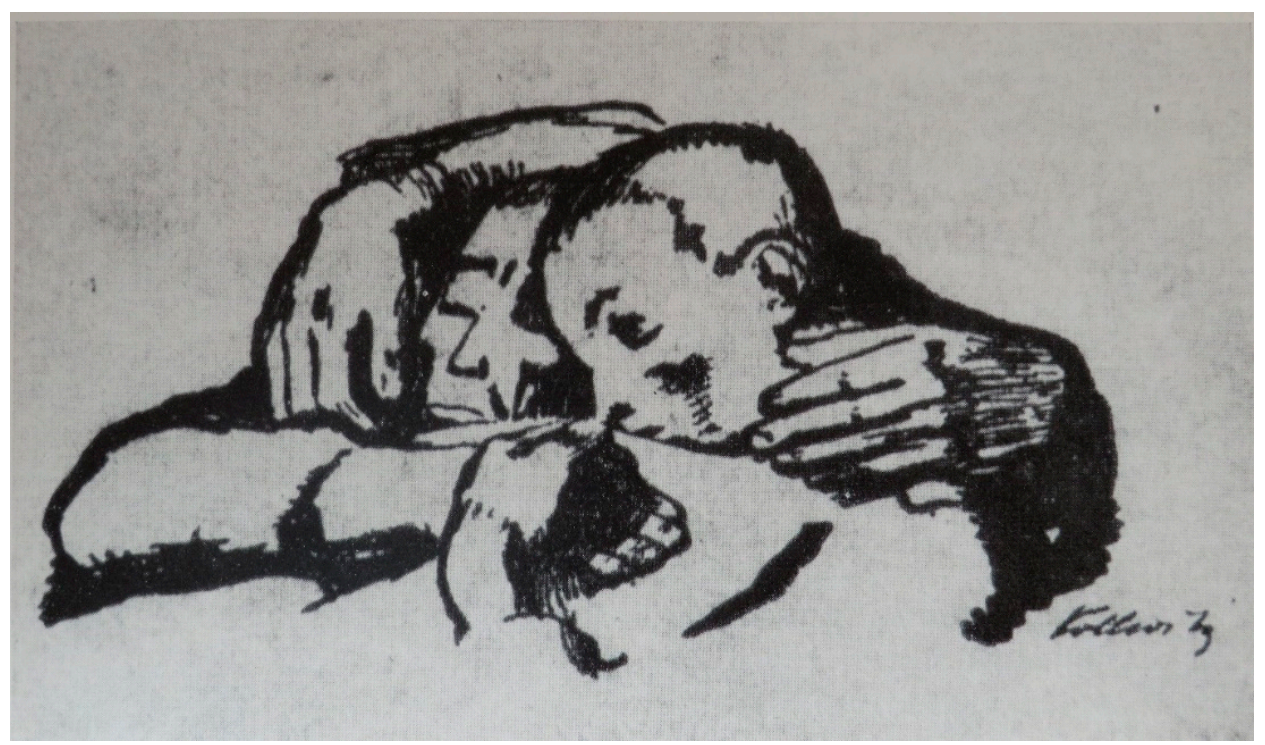

Figure 1. Käthe Kollwitz, Two Dead [Zwei Tote], 1920. Pen and ink, dimensions unknown. According to (Nagel 1972), the original drawing is lost. Image source: (Nagel 1972, p. 355).

While creating Two Dead, she began to develop the spare compositions that characterize War, where emotional impact was drawn from a carefully chosen motif pared down to retain only its essential elements, keeping the viewer's eye firmly focused on the subject. The preliminary drawings for Two Dead are insightful in this respect: a sheet of sketches in black chalk containing six variations shows the two figures always huddled together but variously side by side or facing each other, and varying between head and shoulders only or roughly half figure length studies. One of two further trial drawings, in ink heightened with white chalk, are closely representative of the final drawing, where Kollwitz focuses on the upper body and increases the role of the hands. The hands are now arranged to frame the figures' heads and emphasize the physical closeness-and collapse of animosity - between the youthful figures as they die. ${ }^{18}$ Kollwitz had used faces and hands to deepen the emotive effect in earlier works, including Woman with Dead Child (eight proofs, 1903); here, they work to concentrate the message of Rolland's drama with great economy and power.

Having resolved to use woodcut to create the developing War series, she based her first ever woodcut on Two Dead, ostensibly as practice in her newly adopted technique and in developing her own antiwar language (Figure 2). The woodcut is verified by a diary entry and a letter, confirming that it was created by 25 July 1920: 'My first woodcut is reasonably successful. Now I work with new hope on the preparatory work for the Liebknecht woodcut'. ${ }^{19}$ Relative to her later woodcuts, Two Dead does not take the fullest advantage of woodcut's graphical possibilities, in that she has limited the tonal range on the right, and it seems that Kollwitz did not bother to create a reverse drawing to preserve the integrity of the original composition (only in the woodcut are the figures facing to our right). But the present woodcut is probably only a proof: 'My first attempt at woodcut, based on a title page drawing for Romain Rolland. It is a proof'. No later version of the woodcut is known to have been made. ${ }^{20}$

18 Nagel (1972, p. 355) records three separate sheets with drawings for Zwei Tote. The less developed of the two further drawings (in pencil) is held by the Kollwitz Museum, Cologne (NT (830a)).

19 (Bohnke-Kollwitz 2012, p. 480).

20 Kollwitz, letter to Max Lehrs, 1 February 1921 (Archive of the Staatliche Kunstsammlungen Dresden), quoted in (Nagel 1972, p. 472). Lehrs was the Director of the Kupferstich-Kabinett (Prints and Drawings Cabinet) at the SKD, the first museum to promote Kollwitz, and Lehrs is widely credited with establishing Kollwitz as an artist. 


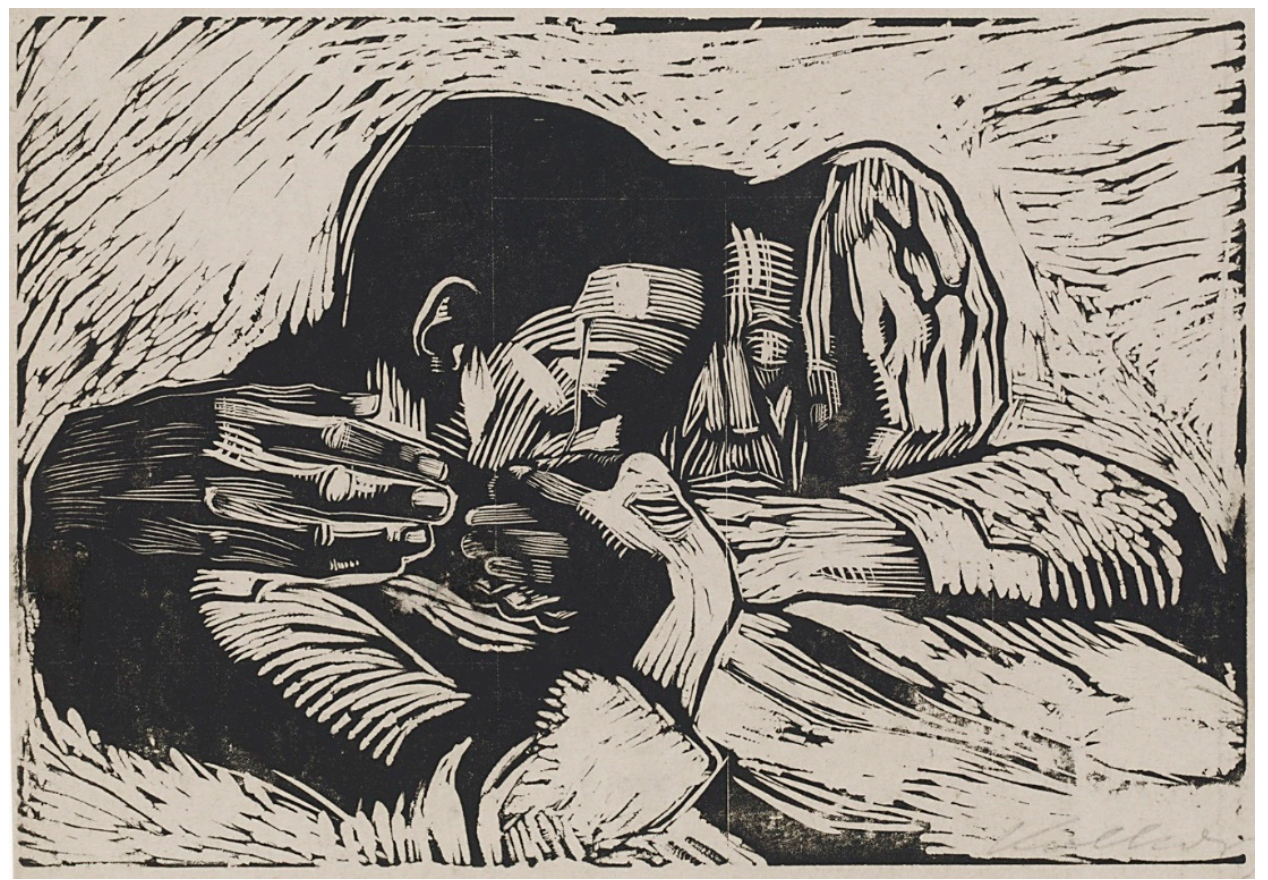

Figure 2. Käthe Kollwitz, Two Dead [Zwei Tote], 1920. Woodcut, $19.1 \mathrm{~cm} \times 27.5 \mathrm{~cm}$. Kn 158 IV, Kölner Kollwitz-Sammlung (C) Käthe Kollwitz Museum Köln.

This initial practice in woodcut helped her prepare for the much weightier responsibility in the case of the Liebknecht print, given the horrific circumstances of his death and its impact on Berliners. Liebknecht and Rosa Luxemburg had led the Spartacist Uprising (5-12 January 1919), in the wake of the lost war. Both leaders were tortured and murdered on 15 January 1919 by the Freikorps, which Kollwitz noted in her diary on 16 January as the 'vile, outrageous murder of Liebknecht and Luxemburg'. ${ }^{21}$ Kollwitz agreed to his family's request for a deathbed portrait and was permitted to make drawings of Liebknecht as he was laid out in the morgue and where mourners continuously filed by. ${ }^{22}$ Accompanied by her son Hans and husband Karl, and longtime friend Stan Harding-Krayl, the correspondent for The Times in Germany who also sketched Liebknecht, she made at least four of a total of at least six, seemingly quite faithful sketches of the dead Liebknecht, with his 'shot-up forehead, the face proud, the mouth somewhat open and painfully distorted' and the 'hands folded over one another', as well as at least twenty-four direct studies of the mourners. ${ }^{23}$ Four drawings are in profile (three of the right side of the face and one of the left) and two in roughly three-quarter to full-face view. One of the profile drawings, executed in black, red, and green chalk (the others are composed of either charcoal or black chalk), and the more developed of the full-face portraits (both in charcoal) were possibly created at home rather than at the morgue, along with further studies of the mourners. ${ }^{24}$ The final composition was developed through further drawings, where she appears to have prepared first for a print in etched or lithographic form and then for a woodcut, given that the later drawings are more tonally limited and use strong, emphatic lines. After testing the print as an etching and as a lithograph, she finally trialed the woodcut, arriving at the final result with the third proof. ${ }^{25}$ The arrangement of the figures borrows from earlier preparatory sketches for In Memory

21 (Bohnke-Kollwitz 2012, p. 400).

22 See timeline of the artist's life on the website of the Käthe Kollwitz Museum, Cologne: https://www.kollwitz.de/zeitstrahl. 3 Diary, 25 January 1919 (Bohnke-Kollwitz 2012, p. 402).

24 See (Nagel 1972, pp. 340-52).

25 Käthe Kollwitz, Memorial Sheet for Karl Liebknecht, 1920. Woodcut, $34.9 \mathrm{~cm} \times 49.9 \mathrm{~cm}$; sheet: $47.7 \mathrm{~cm} \times 63.7 \mathrm{~cm}$. The final print, together with other versions and a number of preparatory drawings can be viewed on the website of the Käthe Kollwitz Museum, Cologne: https://www.kollwitz.de/gedenkblatt-fuer-karl-liebknecht. 
of Ludwig Franks (1914, Figure 3), originally destined for reproduction in the magazine Kriegzeit in September 1914, but abandoned. ${ }^{26}$

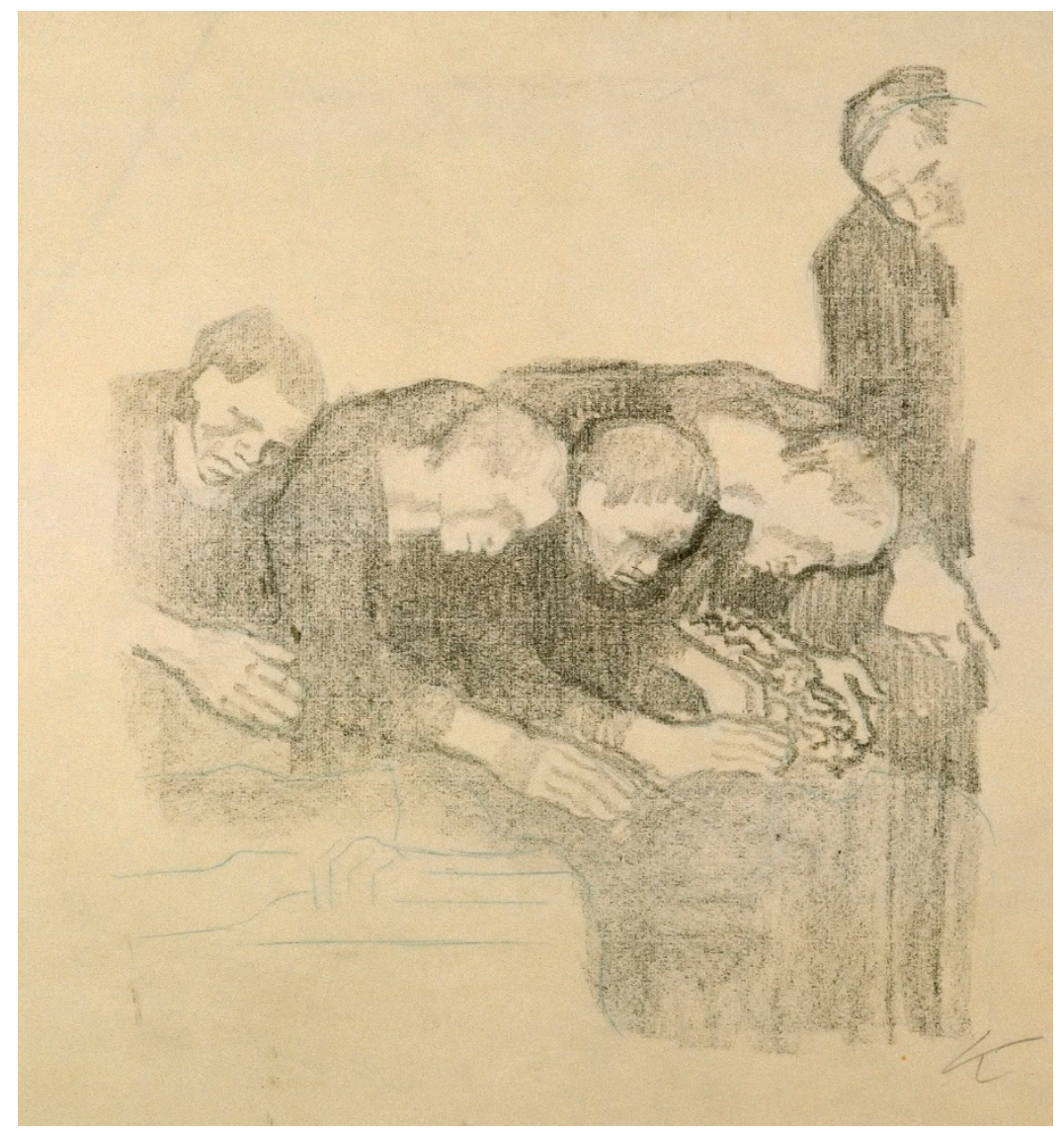

Figure 3. Käthe Kollwitz, In Memory of Ludwig Franks [Dem Andenken Ludwig Franks], rejected second version, 1914. Chalk lithograph (from an unknown drawing on laid paper), $33.7 \mathrm{~cm} \times 30.6 \mathrm{~cm}$. Kn 131, Kölner Kollwitz-Sammlung (C) Käthe Kollwitz Museum Köln.

Kollwitz had created a plaster model for a sculpture in 1915/16 titled Dead Soldier (Figure 4), which may also have inspired the arrangement of Liebknecht's body in the print. ${ }^{27}$ In repurposing these compositions for the Liebknecht work, Kollwitz gradually includes greater variation in the drawing of the mourning figures and embraces the striking linear and tonal contrast of woodcut. The resulting work is a considerable formal departure in Kollwitz's oeuvre, due not only to the tonal economy demanded by her newly adopted medium as well as its intrinsic graphic nature, but also Kollwitz's compositional strategy, which would later come into full play in War. First of all, she reduced the surrounding space visible in the 1914 work to concentrate the viewer's attention exclusively on the mourners and the dead Liebknecht, thus intensifying the drama and emotiveness. Secondly, while she made careful studies of Liebknecht's face, the finished work-in which the facial features are somewhat vague-was designed, as the words at the bottom indicate-The living to the Dead. In Memory of 15 January 1919—as a portrait of his deeply consequential loss for working-class Berliners.

26 See the information on the webpage for the drawing on the website of the Käthe Kollwitz Museum Cologne: https: //www.kollwitz.de/dem-andenken-ludwig-franks.

27 This sculpture (German: Liegender toter Soldat or Toter Soldat), now known only through the photograph, formed part of an abandoned design for a three-figure memorial (father, mother, son). Kollwitz later created the two-figure work Grieving Parents (1932), now at Vladslo German war cemetery, Belgium, where Peter is buried. 'I have begun a work for Peter, to honour him and to honour all the young fallen volunteers. [ ... ] A sacorphagus or rather a smooth, simple long base on which the young dead man lies'. Letter to Beate Bonus-Jeep, (undated/1915), (Bonus Jeep 1948, p. 188). 
Liebknecht's body forms a powerful horizontal foreground plane, with most of the wood cut away to create a broad white swathe that works to separate the viewer, positioned as mourner, and thus completing the composition, from the mourners on the other side. The mourners, indicated chiefly through energetic, multidirectional mark-making in the faces and hand gestures, relieve but never compete with the stillness of Liebknecht's presence. The monumentality Kollwitz achieves is enhanced by the compositional references to many well-known paintings depicting the mourning of Christ, for example Giotto's version at the Arena Chapel in Padua (1305-1306).

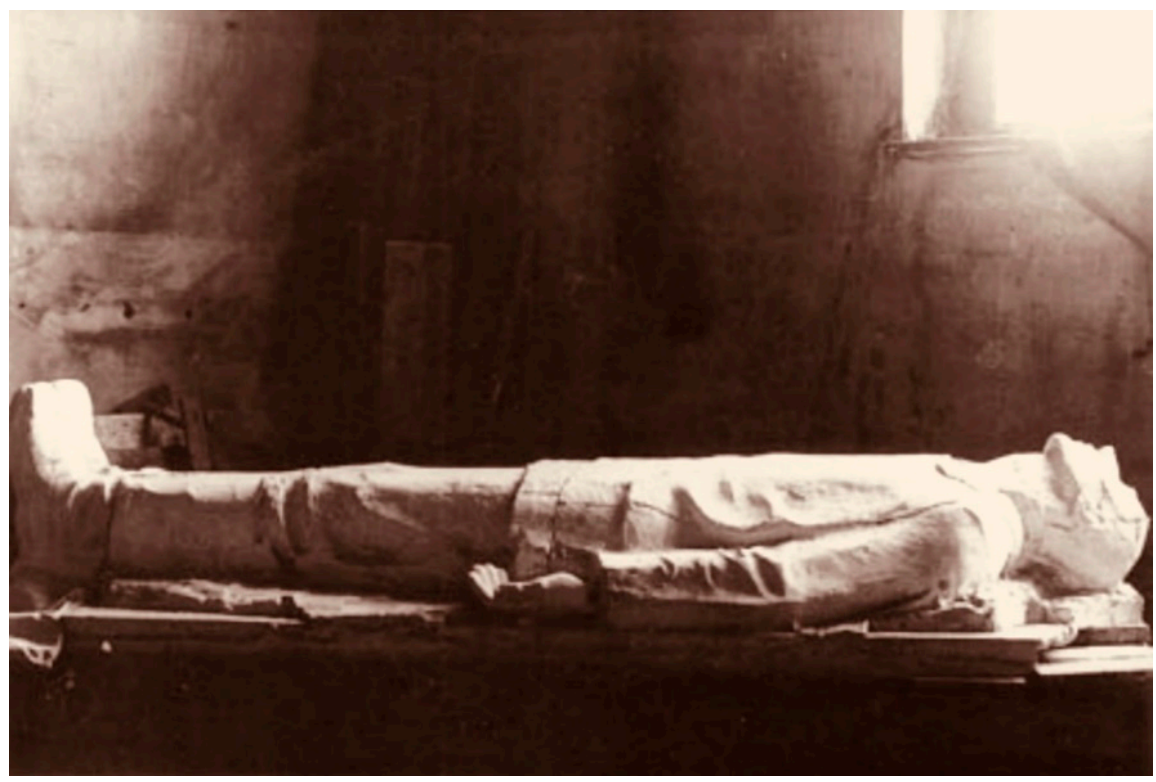

Figure 4. Käthe Kollwitz, Reclining Dead Soldier (Peter Kollwitz), 1915/16. Plaster, dimensions unknown, (presumed lifesize), lost. Model for a three-figure memorial (not completed). Photograph, Landesarchiv, Berlin. Photographer unknown.

The print was included in a solo show for the third Workers' Art Exhibition, organized by Ernst Friedrich, that opened on 1 October 1920 on 39 Petersburger Strasse, Berlin. ${ }^{28}$ However, a review of the exhibition by Gertrude Alexander, who by then was a leading arts and cultural critic in the KPD, levelled heavy criticism at Kollwitz in the KPD's newspaper, Die Rote Fahne. Deriding it as nothing revolutionary, she made no mention of the Liebknecht work and instead focused on Kollwitz's images of the poor:

The deep seriousness of Käthe Kollwitz finds its focus in her devotion to a single earthly phenomenon, the Ecce Homo of the poor and the downtrodden. [ ... ] The swelling richness of human forms [ ... ], the shimmering realm of infinite beauty-all this is hateful to her. In the one gloomy theme, she finds her one and only language. ${ }^{29}$

Alexander's slight was likely due to Kollwitz's known rejection of Liebknecht's politics. In a diary entry that ended with a note on the Rote Fahne's criticism, Kollwitz wrote that she had the right, as an artist, to record the farewell of the workers to Liebknecht—-to dedicate the print to the workers-without following Liebknecht's politics:

I even still say to myself, if it came to a choice between the dictatorship of Ebert and the dictatorship of (Spartacist leader and Communist Party founder Karl) Liebknecht, I certainly

28 (Käthe Kollwitz-Museum 2017, p. 95).

29 (Alexander 1920, p. 5). Kollwitz noted the criticism in her diary in October 1920 (no exact date given). See (Bohnke-Kollwitz 2012, p. 483). 
would vote for Ebert [ ... ] I have lived through the war and seen Peter and the thousand other youths die; I am horrified and shocked by all the hate that is in the world. I yearn for socialism, which allows men to live, and think that the earth has now seen enough of murder, lies, destruction, mutilation, in short everything devilish. The communistic state that builds itself thereupon cannot be God's work. ${ }^{30}$

Overall, Kollwitz's position indicates a view of Liebknecht's death as a tragic consequence of war rather than any admiration of Liebknecht the revolutionary, making the print, in essence, an antiwar work.

The pictorial strategy Kollwitz initiated in Two Dead and the Liebknecht print, that synthesized form and subject in dramatic, carefully distilled, pared-down compositions, was perfected, arduously, in War. ${ }^{31}$ The various drawings and print trials for the cycle, alongside her diary entries and letters, offer fascinating insight to Kollwitz's process, where she variously rejected or developed ideas and tested the final compositions through various stages. The first woodcut trial, according to Alexandra von dem Knesebeck's catalogue raisonné of the prints, was in early 1921, with one of the heads in the first print in the cycle, The Volunteers. ${ }^{32}$ Only by 30 April 1922 does she finally report good progress: 'Plans for woodcuts which are going along with the series on war'. Also noting her new poster regarding postwar food shortages in Vienna, she writes that 'the more I work, the more there dawns upon me how much work there is still to be done'. ${ }^{33}$ By then, she appeared to have dispelled some insecurities - she admitted to being extremely envious of Ernst Barlach, her colleague at the Prussian Academy who, she felt, was 'so much more profound and powerful than I am' ${ }^{34}$ Finding support in a letter (now lost) from Rolland, dated 17 October 1922, ${ }^{35}$ her intentions for the War cycle are made clear in her response on 21 October 1922:

Your letter and greeting were for me a great pleasure. Throughout the war, in the four dark years, your name-and a few others—-was a kind of comfort. Because you represented what one longed to hear. I thank you for remembering our dead son. It's been eight years today since he fell. He was in the field for ten days, then his eighteen-year life ended. He went believing and died like that. His friends had it even harder, all of whom fell in the course of these four years. Their faith faltered and became hate and disgust with the war. But the war did not release them, they almost all had to bleed to death in their most beautiful youth. All of us-in all the warring countries-have borne the same. I have tried again and again to represent the war. I could never grasp it. Now finally I have completed a series of woodcuts which to some extent say what I wanted to say. [... ] These prints should travel everywhere and should summarize to everyone: that is how it was-that is what we have all borne during these unspeakably difficult years. ${ }^{36}$

Writing in her diary in late 1922, following her attendance in a gathering at the Reichstag memorial to commemorate the war dead, she expressed contentment that she was involved with an international society opposed to war (in 1919 she became a member of the main committee of the Bundes Neues Vaterland (from 1922 Deutsche Liga für Menschenrechte), one of the most important German pacifist

30 Diary entry, October 1920 (no exact date given), (Bohnke-Kollwitz 2012, p. 483).

31 Käthe Kollwitz, War, 1918-22/23. Cyle of seven woodcuts, slightly variable proportions, average size $47.5 \mathrm{~cm} \times 65.4 \mathrm{~cm}$. The entire cycle of War, together with various preparatory prints and drawings, can be viewed on the website of the Käthe Kollwitz Museum, Cologne: https://www.kollwitz.de/folge-krieg-uebersicht.

32 (von dem Knesebeck 2002, p. 496).

33 (Kollwitz 1988, p. 530; Bohnke-Kollwitz 2012).

34 Kollwitz had been elected to the Prussian Academy in 1919, the first woman so elected in over a hundred years. Kollwitz had just seen Barlach's play, Die echten Sedemunds (1921). Barlach created numerous antiwar prints and sculptures in the postwar period.

35 Bohnke-Kollwitz (2012, p. 540). 'I have received a good letter from Romain Rolland' [Ich habe einen guten Brief von Romain Rolland bekommen].

36 Ibid., pp. 877-78. 
associations), and while she felt that she did not achieve 'pure art in the sense of Schmidt-Rottluff's [ ... ], it is still art. [ ... ] I am content that my art should have purposes outside itself. ${ }^{37}$ Reporting that she is finished with the war cycle at the beginning of December 1922, she goes back to the print The Parents, because 'it is far too bright and hard and clear. Pain is very dark'. By February, she finally completed the cycle. ${ }^{38}$

The prints distil the mainly civilian experience of war in a remarkably succinct visual style, focusing on some of the most prominent aspects of civilian war experience. The concept for the first of these, The Sacrifice, appears in a diary entry describing the 1915 drawing on the theme, Standing Mother, Pressing Baby to Face, that predates War: 'I am working on the offering. [The woman] bows far forward and holds out her child in deepest humility'. In the 1915 drawing, the woman clings to the child, not wanting to be parted from it. But here, the woman proffers the child, more clearly reflecting Kollwitz's and other women's experiences at the outset of war-that it was their expectation as women to give up their sons to fight in the war. ${ }^{39}$ The Volunteers is perhaps the most discussed of the cycle, and as often noted, references a popular theme in German culture, the Dance of Death. A hand at the top left signals the call to duty, inciting 'the dance' - the often-cited rush to join the ranks in August 1914. Kollwitz places her son's image closest to Death-reflecting the fact that he died in the earliest weeks of the war. The figures, enveloped in blackness, are hypnotized, helpless to resist the 'dance' which will result in what Kollwitz sees as the needless mass demise of German youth. The print clearly mirrors the feeling of betrayal felt by many, where the imperial government's propaganda induced many youths to 'defend' Germany.

The Parents reflects the suffering of parents, and its design formed the starting point for a sculpture. It was also the print that seemed to give her the most difficulty and was the last of the series to be completed. After abandoning the version completed in December 1922, she created a tonally much darker one (as she suggested), where the figures are literally cloaked in darkness. The background, completely cut away, leaves only the two parents whose bodies are indicated with the lightest of cutting. The hands are again used carefully to convey meaning: the slumped hand of the distraught mother, the father's hand supporting her and the despair expressed by the hand on the father's head, its expressiveness emphasized by the deeply contrasting light and shade on the contours of the hand. The Widow I depicts a desolate young woman who is heavily pregnant and expresses, among other things, the destitution of families who had lost fathers and husbands and were left to face the postwar economic vicissitudes alone. This theme was repeated in numerous works by Kollwitz in the postwar years.

The composition and context of The Widow II, the fifth in the cycle, underwent several reconfigurations, including a disturbing lithograph showing the dead mother floating in water, facing away from the viewer, holding her dead child. ${ }^{40}$ It also recalls a much earlier work, Raped [Vergewaltigt], part of the Peasant War [Bauenkrieg] series of etchings (1903-1908), which portrayed the suffering of peasants in sixteenth century Germanic lands. While recalling the many deaths caused by wartime destitution, it is also the only plate that suggests the aftermath of a violent act on individuals. We are presented with a woman lain on the ground and who appears to be dead or dying. Lying on the ground in this shadowy, nondescript space, her mouth agape, the image indicates that death was not peaceful; perhaps she and the child were victims of the famine conditions in parts of postwar Germany

37 Kollwitz (1988, p. 104). See (Bohnke-Kollwitz 2012, p. 542). The English translation gives no specific date (November 1922). Bohnke-Kollwitz dates the entry as 4 December 1922.

38 (Bohnke-Kollwitz 2012, pp. 542-43, 548).

39 Kollwitz (1988, p. 64). See (Bohnke-Kollwitz 2012, pp. 184-85). Standing Mother, Pressing Baby to Face, 1915, charcoal on grey paper fixed with shellac, Käthe Kollwitz Museum, Cologne.

40 The Widow II (discarded first version), before May 1920. Lithograph, $38 \mathrm{~cm} \times 62 \mathrm{~cm}$. Dr. Richard A. Simms Collection, Getty Research Institute, Los Angeles. Nagel (1972, pp. 386-87) records two related drawings. Knesebeck records one lithographic trial for the first version (von dem Knesebeck 2002, pp. 462-63), one lithograph and two woodcut states for the second version (ibid., pp. 464-65, 528-29) and seven states of the final woodcut composition (ibid., pp. 530-33). 
and Austria, or they were murdered; the unnatural position of the woman's head suggests that the neck has been wrenched. Importantly, Raped and The Widow II register the inescapability of suffering during wartime. The Widow II showed that even if German territory was virtually untouched by the war, German civilians were not. The print borrows the strong diagonal placement of the body on the ground and the positioning of the head in Raped, though in The Widow II, the head is placed closest to the viewer. Nonetheless, we are denied direct engagement with the face, which preserves the sense of abandonment and anonymity in Raped. Additionally, the presence of a small, frightened child hidden from the rapists in the 1908 work, and as subtly placed, is repeated in The Widow II; but this time the child too appears dead, slumped lifelessly in its mother's right arm. Thus, the tragedy and viciousness in The Widow II appears complete. The Mothers shows a tightly packed group of mothers protecting children. ${ }^{41}$

The final print, The People, groups together figures representative of some social groups who felt the consequences of the war most profoundly. At the center is a woman, eyes mournfully cast downward, her hand placed protectively over the child who emerges from the blackness of her clothing, and who is placed, symbolically perhaps, at the womb. She is somewhat ageless, representing every woman-mother, wife, sister, grandmother-who became the victim of the war on the home front. She and the child are surrounded by five figures, all apparently male. On the left, a man clenches his fists tightly to his face, the deeply furrowed brow suggestive of angst. To the right is a figure with somewhat twisted features and teeth bared, surrounded by lines that suggest agitated movement. This figure is possibly representative of the many thousands of men who returned from the war with mental trauma.

In these spare compositions, Kollwitz excludes all references to place or time, making them truly universal expressions of antiwar sentiment. The cycle was published in three editions, the first, Edition A, being published in portfolio form. ${ }^{42}$ While these editions allowed for limited dissemination, the works achieved further exposure through periodicals and exhibitions. An article on Kollwitz by Dora Wentscher in the pacifist journal Die Weltbühne on 24 January 1924 described her graphic work as an 'ever-increasing force [that] indicted the civilized world for the murder of human beings and souls' and described War thus:

[The Widow II] beaten to the ground by grief, lies numb on the white [ground]. Naked and far away, icy feet rise up; thrown over her chest and neck, the tired weeping child sleeps. But over him, in sleep still protective [ ... ] the clammy hand of the unconscious, frozen body. [ ... ] The Volunteers, with Death leading the way into the blackness. [... ] And then, sublime form: the chapel of sorrow built from the bodies of father and mother, fused together from wailing for the fruit of their love, which is unripe, prematurely rotting under the earth. [In The People], the face of a female martyr, of will incarnate, determined to give and protect the life and beauty in her womb. A humanity that contains powers like the soul of this woman, this humanity will not perish, mangling itself. Maternal love, that is the beginning of all things, in Käthe Kollwitz stands up to call and warn. 0, that all continents would hear it! ${ }^{43}$

Kollwitz took part in an exhibition of antiwar art and photographs of men maimed by warfare in the newly founded International Antiwar Museum at 29 Parochialstraße, Berlin, launched to coincide with the tenth anniversary of the outbreak of World War I. Kollwitz had been acquainted with the museum's

41 This print's composition reappears in sculpted form in Tower of Mothers (1937/38). Kollwitz had noted the idea of creating a sculpted version of the print on 30 April 1922, describing it as a circle of standing mothers protecting their children, sculpted in the round. See (ibid., pp. 530-31).

42 (von dem Knesebeck 2002, pp. 173-76, 178-79, 190). Edition A of 100 was printed on imperial Japan paper; Edition B of 100 was printed on wove paper, and Edition C of 200 was printed more cheaply from an electrotype plate on imitation Japan paper. Edition A: Käthe Kollwitz, Krieg, 1923. Portfolio of seven woodcuts and one woodcut cover (Die Witwe I), each sheet approx. $47.6 \mathrm{~cm} \times 65.9 \mathrm{~cm}$. Emil Richter, Dresden.

43 (Wentscher 1924, pp. 110, 112). 
founder, the remarkable Ernst Friedrich, since at least 1921, when one of her drawings featured on the front cover of his Proletarischer Kindergarten. Ein Märchen- und Lesebuch für Groß und Klein [Proletarian Kindergarten-A Fairytale and Reading Book for Young and Old], an anthology dealing with typical socialist topics such as state and church, enlightenment, big cities, and solidarity, including texts on war. $^{44}$ When the museum was officially opened a year later, on 1 August, 1925, Kollwitz's and Dix's prints were included. The Berliner Tageblatt reported:

When one enters the hall, which serves the purpose of the museum for the time being, [ ... ] the first thing that is striking is the bloodcurdling domestic war etching by Käthe Kollwitz and engravings by Dusseldorf's Otto Dix. Pictures of horror! Shaking your head, you turn away. ${ }^{45}$

While Friedrich's collection of photographs and Dix's visceral imagery ensured that the German people, whose territory was virtually untouched, would be exposed in some way to the carnage of the Belgian and French battlefields, Kollwitz's prints were a reminder of the widespread suffering of ordinary people on the home front. From 1925, Kollwitz's work also illustrated some issues of Friedrich's newspapers Die Schwarze Fahne and Neue Jugend (Figure 5). Friedrich put on view numerous photographs of the physically maimed, including many of the Gueules cassées-the men whose faces were disfigured-alongside some of Otto Dix's suite of fifty etchings entitled The War and Kollwitz's seven woodcuts.

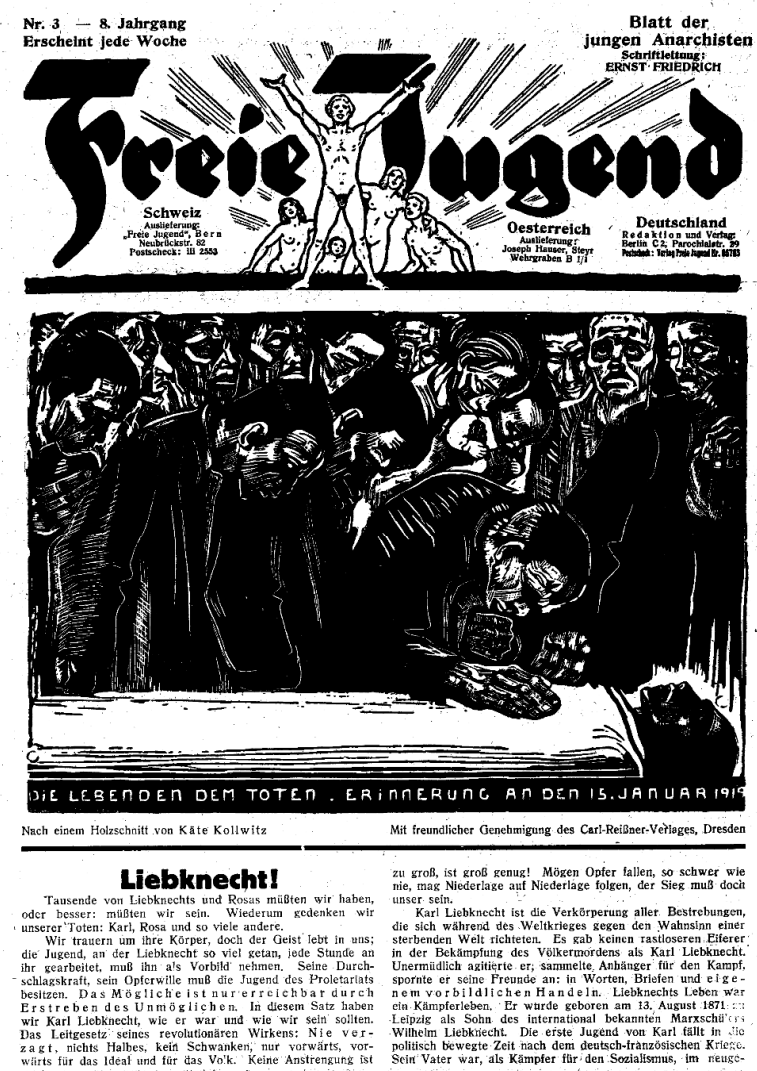

Figure 5. Front page of Freie Jugend, Week 3, Volume 8 (c. 21 January 1926), illustrated by Kollwitz's Memorial to Karl Liebknecht (1920).

44 (Friedrich 1921). The book featured work by Otto Nagel and others in addition to Kollwitz.

45 (Spree 2017, p. 56). 
By this time, Kollwitz had completed numerous posters, including one commissioned by the German Communist Party (KPD) for an issue that had been burning since 1871-Paragraph 218 of the Abortion Bill and titled Nieder mit den Abtreibungsparagraphen! [Down with the Abortion Paragraph!] and the other for the Internationale Gewerkschaftsbund (IGB, International Federation of Trade Unions-IFTU) titled The Survivors [Die Überlebenden] (Figure 6). ${ }^{46}$ As Jutta Bohnke-Kollwitz noted, this and other antiwar posters were very important to the artist, and she worked hard to make them effective, for both their connection to the memory of her dead son and in her commitment to the antiwar campaigns. ${ }^{47}$ Regarding The Survivors, Kollwitz wrote to her friend Beate Bonus-Jeep that 'the Federation of Trade Unions senses all new frightening possibilities of war and wants to make counter propaganda. Large posters, which logically recall the consequences of the war, are published in fourteen European countries. The first poster was made by Steinlen, the second I should make. You can imagine how completely I am going to do that' ${ }^{48}$ The first printing alone amounted to a thousand copies, with, below the image, the inscriptions 'The Survivors' to the left and 'No more War' to the right in German, Swedish, Danish, and Dutch. In the poster, a gaunt mother holds to her three of the young children in the foreground, while among the figures in the background are two blinded war veterans. $^{49}$

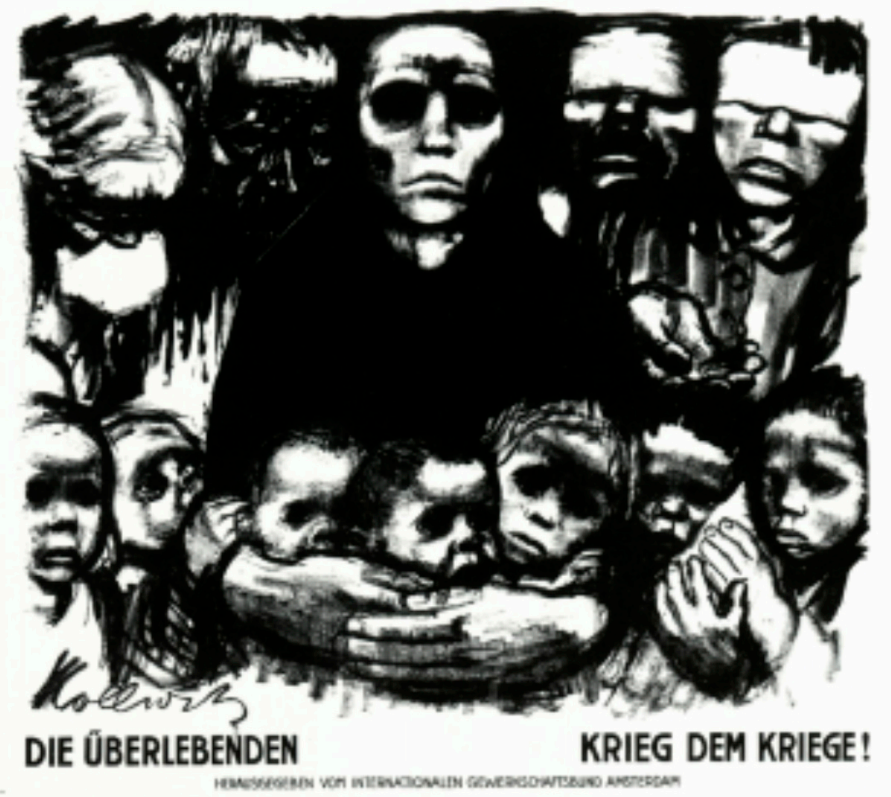

Figure 6. Käthe Kollwitz, The Survivors, 1923. German version of the poster. Based on the lithograph of the same name on beige wove paper, 1923. $56.2 \mathrm{~cm} \times 68.5 \mathrm{~cm}$. See (von dem Knesebeck 2002, pp. 582-85).

46 Kollwitz, Nieder mit den Abtreibungs-Paragraphen [Down with the Abortion Paragraph], 1923. The prohibition was entered into the Criminal Code of the German Empire in 1871, and meant that a woman who underwent an abortion as well as whoever performed the abortion would receive a prison sentence. See for example (Hille 2017, pp. 183-95). The new independence of women, brought about by the new dependence on women as a consequence of the war effort, and particularly because women had been granted suffrage on 30 November, 1918, brought the issue of the Abortion Paragraph to a head because it was a tax on women's autonomy.

47 Bohnke-Kollwitz (2012, p. 880) also notes that they were also important for financial reasons: 'With some relief, she writes to her son Hans on 21 September: "Today comes [Edo] Fimmen and brings me 200 Dutch guilds for the antiwar poster"'. Fimmen was Secretary General of the IFTU.

48 Kollwitz, quoted in (von dem Knesebeck 2002, p. 585).

49 Another version of the poster was printed for the German antiwar day on 21 September 1924, with the same text as before and with additional text beneath: Antikriegstag am 21 September 1924. The Internationale Gewerkschaftsbund are credited in smaller text at the bottom left. See von dem Knesebeck (2002, pp. 582-85) for this and further details regarding the various international versions of the poster. 
But it was another poster, Nie wieder Krieg! [No More War!] that became (and remains to this day) one of the most potent symbols of the international peace movement. One of its first public appearances was as a large front-page illustration in a special antiwar edition of the newspaper, the Leipziger Volkszeitung, published on Saturday, 2 August 1924, the day before the Nie wieder Krieg! [No more War!] rally on the Augustusplatz in Leipzig, organized as part of the Central German Youth Day of Socialist Youth Workers [Der Mitteldeutsche Jugendtag der Sozialistischen Arbeiterjugend] (Figure 7). It is arguably her most perfectly distilled, politically charged visual statement. The three drawings and the single version of the lithographic print indicate that she had decided on its design quite quickly. The figure is androgynous in appearance, and this vagueness seems deliberate: as neither expressly male nor female, the figure becomes universally representative of antimilitarism, while the figure's youthfulness was fully in keeping with an event that sought to heighten antiwar awareness in a generation that was too young to go to war in 1914 and which evidently included many who lamented the fact. $^{50}$

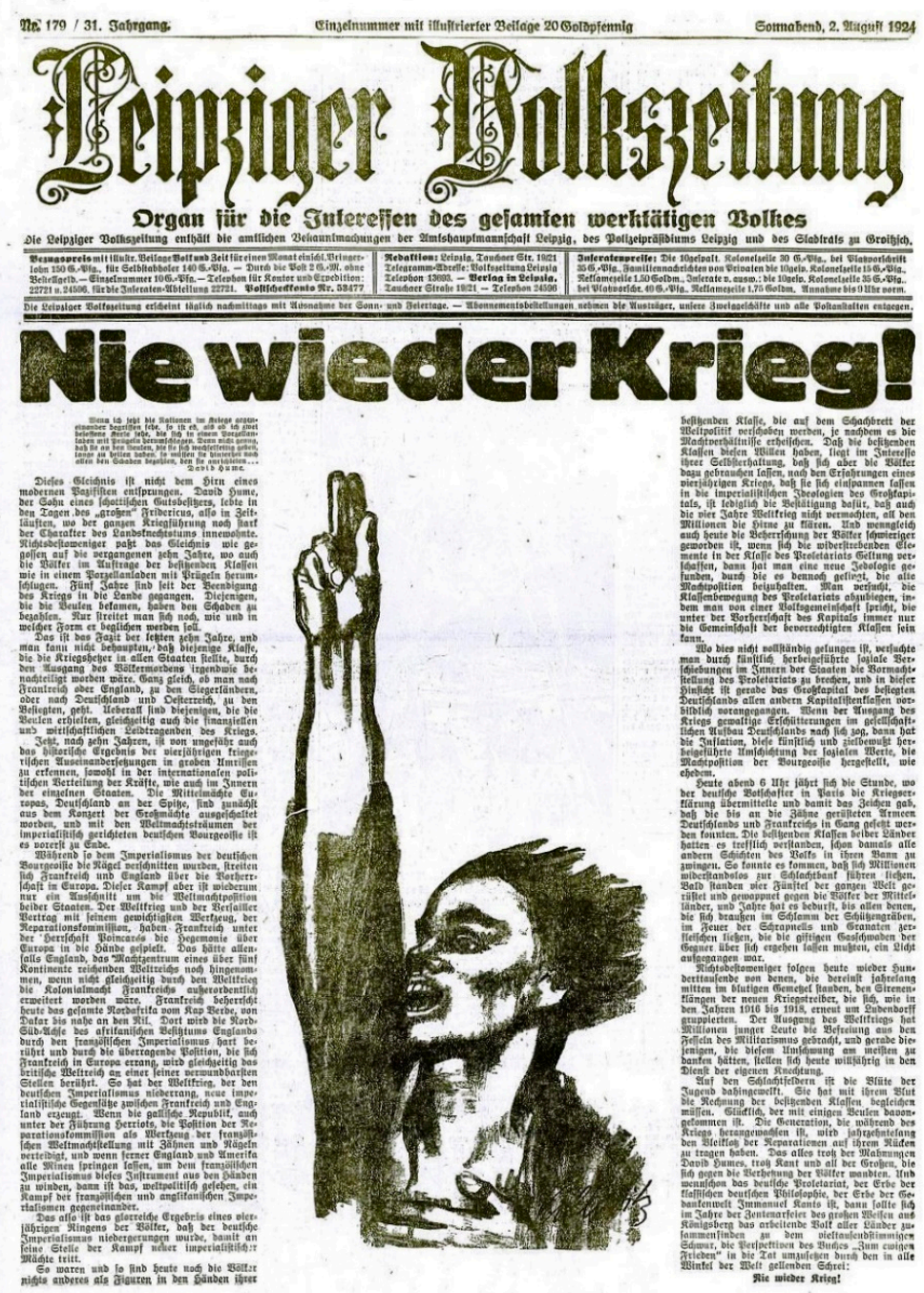

Figure 7. Front page of the Leipziger Volkszeitung, Saturday, 2 August 1924, with an illustration of Kollwitz's No More War poster figure.

50 The previously mentioned Freikorps included many young men who were too young to fight in 1914. Kollwitz did not define the figure in Nie wieder Krieg! as either male or female in her written accounts. 
The figure's raised hand is the Schwurhand [oath hand], intended to corroborate the words spoken when taking an oath. The centuries-old Schwurhand had long been in use in Germany, for swearing an oath in court or swearing in politicians elected to government posts, for example. Kollwitz may have also taken her inspiration from youth worker Max Westphal during the first Reich Youth Day of the Socialist Youth Workers (1920), when he stretched out his one arm (he lost the other in the war) as a Schwurhand, and exclaimed 'never again war'. ${ }^{51}$ Typically, as in Kollwitz's poster, the right hand is raised, the palm of the hand facing the viewer, the thumb, index, and middle fingers (the Schwurfinger) stretched parallel to each other and the ring and little fingers bent. In its religious (Christian) connotations, the oath hand symbolizes the subjugation of the people under the Trinity of God the Father, Jesus, and the Holy Spirit. As such, the gesture indicates a promise never to go to war again. Illustrations of work by Kollwitz's contemporaries, Leipzig-born George Kretzschmar, who had served in the war, and the pacifist Flemish artist Frans Masereel, who, because he had refused to fight, was forced to live outside Belgium for several years, were shown on internal pages as well as the satirical work, Peace, an Idyll, by nineteenth century French artist and satirist Honore Daumier (1808-1879. ${ }^{52}$ Among the literary contributors was a young Walter Mehring, one of the most prominent satirical writers of the Weimar Republic, with his essay Der Aufbruch zur Front [The Departure for the Front], reproduced on page two of the accompanying feuilleton. ${ }^{53}$

The content of the special edition of the Leipziger Volkszeitung was drawn from the lengthier book Nie wieder Krieg!, published by the West Saxony branch of the Sozialistischen Arbeiter-Jugend and which included several reproductions of Kollwitz's War cycle: The Sacrifice, The Volunteers, The Widow II and The Mothers. ${ }^{54}$ As in the Leipziger Volkszeitung, the first image encountered by the reader was the androgynous figure in Kollwitz's poster, this time on the book jacket. Reviewing Nie wieder Krieg!, the young Dora Heinemann emphasized the importance of Kollwitz's and other creatives' voices in the antiwar campaign:

Under this title the Socialist Workers' Youth, West Saxony District, publishes an excellent small publication. It is so important and so valuable to us pacifists because it expresses the determination, the unconditionality and the will to act of those who are most important, the masses of youths who would be the army in the next war. [ ... ] This colourful muddle of visual arts, poetry, politics and science, which stand side by side here, becomes the most wonderful coexistence of various forms of expression for equal paths, for equal will. In addition to pictures by Käthe Kollwitz, Dix, George Groß, Masereel, there are words by Toller, Eisner, Engelke. The eternally young, Karl Liebknecht and Rosa Luxemburg, again have their say in this book of youth. [ ... ] This manifesto should be available to all those who want to learn from a truly young, antimilitarist fighting spirit. ${ }^{55}$

Thus Kollwitz's antimilitarist art was again enmeshed with the leading antiwar voices of the day, including that of famous left-wing expressionist poet and playwright, Ernst Toller, whose contribution was his antiwar poem, Marschlied [Marching Song] (1915). A bilingual French and German edition of Nie wieder Krieg! was published in 1925, preserving Kollwitz's poster figure as the cover image as well as the woodcuts from Krieg. Also included was a report by Toller on the 2 August, 1924 antiwar rally in Leipzig, illustrated by Kollwitz's Sacrifice. ${ }^{56}$

51 For the reference to Westphal, see the website of the Käthe Kollwitz Museum, Cologne: https://www.kollwitz.de/plakat-niewieder-krieg.

52 The reproductions of Kretzschmar's works were Das Gespenst des Krieges [The Spectre of War] and Der Schutzengraben [The Trench]. Masereel's were Das ist kein Traum [This is not a Dream] and Die Toten reden [The Dead are Talking].

53 Mehring also contributed to Die Weltbühne, edited by Kurt Tucholsky up to 1927 and then by Carl von Ossietsky.

54 (Kühn 1924).

55 (Heinemann 1924). The precocious journalist and writer Heinemann was committed to social justice from an early age, and became a fervent anti-Nazi activist. She was found dead in London, under mysterious circumstances, on 4 April 1935.

56 (Kühn 1925, pp. 66-68). 
In Nie wieder Krieg, Kollwitz's woodcut The Mothers appeared alongside a poem of the same name by Toller. Toller had served in the war and suffered psychological collapse as a result, and subsequently spent years campaigning against militancy. In this poem, he describes how unlike idealized portrayals of battlefield burials, the bodies of the mothers' dead sons lay decomposing on the rippled land or trapped in barbed wire, or how they returned home crippled or blind. Another woodcut from War, The Volunteers, accompanied an essay by prominent antiwar campaigner Helene Stöcker, with whom Kollwitz was acquainted since at least 1920. Entitled Militarism, War and Sexuality, it discussed war as an inevitable consequence of militarized culture. Stöcker had founded Paco (the Esperanto word for 'Peace') in Bilthoven, Holland in 1921, which was later known as the War Resisters' International and is still active today.

These activities reveal how deeply embedded Kollwitz was in the No More War campaign, both in Germany and internationally, as well as the pragmatism and earnestness she committed to the creation of the works. While her work was not alone in contesting the abstract concepts of honor and glory attached to the popular memorialization of the war in Weimar Germany, where she and other artists and writers refused to heroize individuals or any aspect of war, her elimination of references to a specific time or place made her work universally legible indictments of the real sacrifices demanded by World War I in every nation. Within the considerable body of antiwar art produced in German during the Weimar era and beyond, her War cycle remains a singular, universal antiwar statement of the home front experience of war. ${ }^{57}$

Kollwitz's activism, through her art, continued into the Nazi era. As her son Hans recalled, 'when Nazism came knocking at the gates, she publicly took sides against it and accepted the consequences' ${ }^{58}$ And the consequences were considerable. By the late 1930s, they had completely banned her from exhibiting, made at least forty of her works disappear, and had her fired from her professorship at the Prussian Academy in Berlin. She had left her home on Weissenburger Strasse in Berlin before it was destroyed on 23 November 1943. Because she died on 22 April 1945, during the last days of World War II, her work would never be exhibited again during her lifetime. To the end, she held to her belief, No More War, and repeatedly urged that 'idealism and readiness for sacrifice of the young people should be turned not toward war, but toward building a better life and society. ${ }^{59}$

Funding: This research received no external funding. The work of Käthe Kollwitz is in the public domain. The author declares that photographic rights, where the photographer or institution is known, have been granted.

Conflicts of Interest: The author declares no conflict of interest.

\section{References}

Alexander, Gertrude. 1920. Arbeiter-Kunst-Ausstellung. Die Rote Fahne, October 12, 5.

Bader, Herbert. 1979. Nie wieder Krieg. Der Kampf für Frieden und Abrüstung seit 1900. Eine Dokumentation. Berlin: Elefanten Press.

Bessel, Richard. 1993. Germany after the First World War. London: Clarendon Press.

Bittner, Herbert. 1959. Kaethe Kollwitz. Drawings. London and New York: Thomas Yoseloff.

Bohnke-Kollwitz, Jutta, ed. 1992. Käthe Kollwitz, Briefe an Den Sohn: 1904 Bis 1945. Berlin: Siedler.

Bohnke-Kollwitz, Jutta, ed. 2012. Käthe Kollwitz. Die Tagebücher 1908-1943, New edition. Munich: btb.

Bonus Jeep, Beate. 1948. Sechzig Jahre Freundschaft mit Käthe Kollwitz. Boppard: Rauch.

Dehmel, Richard. 1918. Einzige Rettung. Vorwärts, October 22, 7.

Friedrich, Ernst, ed. 1921. Proletarischer Kindergarten Ein Märchen- und Lesebuch für Groß und Klein. Berlin: Buchverlag der Arbeiter-Kunst-Ausstellung.

57 See the aforementioned (Heckmann and Ottomeyer 2009) for insight to German antiwar art during the Weimar Republic. The book includes work by seventy-seven artists.

58 Ibid., p. 8.

59 Ibid. 
Heckmann, Stefanie, and Hans Ottomeyer. 2009. Kassandra. Visionen des Unheils 1914-1945. Dresden: Sandstein. Heinemann, Dora. 1924. Review. Nie Wieder Krieg. Berliner Wissenschafts-Verlag 24: 246-47.

Hille, Karoline. 2017. Paragraph 218 and the "Women's Matter". In Splendour and Misery in the Weimar Republic. Edited by Ingrid Pfeiffer. Munich: Hirmer, pp. 183-95.

Hoffmann, Tobias, ed. 2018. Berliner Realismus. Von Käthe Kollwitz bis Otto Dix. Sozialkritik—Satire-Revolution. Cologne: Wienand Verlag.

Käthe Kollwitz-Museum, Berlin, ed. 2017. Käthe Kollwitz und ihre Freunde. Berlin: Lukas Verlag.

Kollwitz, Käthe. 1918. An Richard Dehmel! Entgegnung von Käthe Kollwitz. Vorwärts, October 28, 3.

Kollwitz, Hans, ed. 1981. "Ich will wirken in dieser Zeit": Auswahl aus den Tagebüchern und Briefen, aus Graphik, Zeichnungen und Plastik, 5th ed. Berlin: Mann.

Kollwitz, Hans, ed. 1985. Ich sah die Welt mit liebevollen Blicken: Ein Leben in Selbstzeugnissen, 8th ed. Wiesbaden: Fourier.

Kollwitz, Hans, ed. 1988. The Diary and Letters of Kaethe Kollwitz. Clara Winston, and Richard Winston, transs. Evanston: Northwestern University Press.

Kühn, Fritz, ed. 1924. Nie Wieder Krieg! Leipzig: Sozialistische Arbeiter-Jugend, Bezirk West-Sachsen.

Kühn, Fritz, ed. 1925. Nie Wieder Krieg. Leipzig: Roter Türmer Verlag.

McCausland, Elizabeth. 1937. Käthe Kollwitz. Parnassus 9: 20-25. [CrossRef]

Mosse, George L. 1991. Fallen Soldiers: Reshaping the Memory of the World Wars. Oxford: Oxford University Press.

Nagel, Otto, ed. 1972. Käthe Kollwitz. Die Handzeichnungen (Catalogue Raisonné). Berlin: Henschelverlag Kunst und Gesellschaft.

Prelinger, Elizabeth. 1992. Käthe Kollwitz. Washington, DC: National Gallery of Art.

Rolland, Romain. 1921. Die Zeit wird kommen. Drama in Drei Akten. Leipzig: EP Tal \& Co. Verlag.

Sharp, Ingrid. 2011. Käthe Kollwitz's Witness to War: Gender, Authority, and Reception. Women in German Yearbook 27: 87-107. [CrossRef]

Siebrecht, Claudia. 2013. The Aesthetics of Loss: German Women's Art of the First World War. Oxford: Oxford University Press.

Spree, Tommy. 2017. Ich kenne keine Feinde. In Krieg dem Kriege. Edited by Anti-Kriegs-Museum. Berlin: Anti-Kriegs Museum.

von dem Knesebeck, Alexandra, ed. 2002. Käthe Kollwitz. Werkverzeichnis der Graphik. Bern: Verlag Kornfeld.

Wentscher, Dora. 1924. Käthe Kollwitz. Die Weltbühne 20: 110-12.

Whitner, Claire, ed. 2016. Käthe Kollwitz and the Women of War. Femininity, Identity and Art in Germany during World Wars I and II. New Haven: Yale University Press.

Ziemann, Benjamin. 2013. Contested Commemorations: Republican War Veterans and Weimar Political Culture. Cambridge: Cambridge University Press.

Zweig, Stefan. 1921. Romain Rolland. The Man and His Work. Translated by Eden Paul, and Cedar Paul. New York: Thomas Seltzer.

(C) 2020 by the author. Licensee MDPI, Basel, Switzerland. This article is an open access article distributed under the terms and conditions of the Creative Commons Attribution (CC BY) license (http://creativecommons.org/licenses/by/4.0/). 